\title{
Pengaruh Substitusi Konsentrat Daun Kering Kaliandra (Calliandra Calothyrsus) terhadap Jumlah Produksi 4\% FCM, Lemak, Bahan Kering, Bahan Kering Tanpa Lemak, Protein, dan Laktosa Susu Sapi Perah Fries Holland
}

\author{
Effect of The Concentrate Substitution Using Caliandra (Calliandra Calothyrsus) Dry Leaf on The 4\% \\ FCM Production, Fat, Dry Matter, Non Fat Dry Matter, Protein, \\ and Milk Lactose of Fries Hollands Dairy Cow \\ Willyan Djaja, S. Kuswaryan, dan U.H. Tanuwiria \\ Fakultas Peternakan Universitas Padjadjaran
}

\begin{abstract}
The aim of the research was to investigate the effect of feeding dried Caliandra leaves on milk production. The research was conducted at Harapan Jaya dairy cattle group, Sumedang. The treatments were R 1 (grass $+100 \%$ concentrate), $\mathrm{R}_{2}$ (grass $+90 \%$ concentrate $+10 \%$ dried Caliandra leaf), R3 (grass $+80 \%$ concentrate $+20 \%$ dried Caliandra leaf), and $\mathrm{R}_{4}$ (grass $+70 \%$ concentrate $+30 \%$ dried Caliandra leaf). Sixteen Fries Holland dairy cattle were used and were divided into four groups. The experimental design used was a randomized block design and the mean of treatments was tested using orthogonal contrast. The results showed that feeding dried Caliandra (C. calothyrsus) leaves were able to substitute concentrate as it increased milk production by $4 \%$. However, feeding dried Caliandra leaves did not affect the milk components of Fries Hollands dairy cattle as described below. 1) There was not a significant difference among the treatments; however, there was a $4 \%$ increase on FCM milk production of Fries Holland cattle (R3). There was not a different on milk components which was based on milk fat production, dry matter production, solid non fat, and lactose production. The results suggested that $20 \%$ substitution of the concentrate using dried Caliandra leaves for feeding the lactating cows was the best method to increase the milk production as well as economical.
\end{abstract}

Key Words: milk production, milk components, dried Caliandra leaves, Fries Holland.

\begin{abstract}
ABSTRAK
Penelitian dilaksanakan di kelompok peternak sapi perah Harapan Jaya, kabupaten Sumedang,dengan tujuan untuk mengetahui pengaruh jumlah pemberian daun kering Kaliandra yang menyubstitusi konsentrat terhadap produksi susu sapi perah Fries Holland. Percobaan menggunakan 16 ekor sapi Fries Hollands(FH) dan dibagi menjadi empat kelompok. Perlakuan terdiri dari $\mathrm{R}_{1}$ (jerami $+100 \%$ konsentrat), $\mathrm{R}_{2}$ (rumput $+90 \%$ konsentrat $+10 \%$ daun kering Kaliandra), $\mathrm{R}_{3}$ (rumput $+80 \%$ konsentrat $+20 \%$ daun kering Kaliandra), dan $\mathrm{R}_{4}$ (rumput $+70 \%$ konsentrat $+30 \%$ daun kering Kaliandra). Rancangan percobaan yang digunakan yaitu rancangan acak kelompok dan pengujian dilanjutkan dengan uji kontras ortogonal. Perlakuan meningkatkan jumlah produksi 4\% FCM susu sapi perah Fries Holland tetapi di antara perlakuan Kaliandra sendiri berpengaruh tidak nyata. Perlakuan R3 memberi hasil susu lebih banya k dibandingkan dengan R1,R2 dan R4. 2) Perlakuan tidak secara nyata $(P>0,05)$ meningkatkan jumlah produksi komponen susu berdasarkan $\mathrm{c})$ Jumlah produksi bahan kering tanpa lemak susu perlakuan $\mathrm{R}_{3}$ lebih bbanyak dibanding R1,R2 dan R4. d) Jumlah produksi protein susu perlakuan R3 lebih banyak dari pada R1;R2 dan R4. e) Jumlah produksi laktosa perlakuan $R_{1}, R_{2}$, $R_{3}$, dan $R_{4}$ masing-masing sebesar $0,454 \pm 0,136 ; 0,551 \pm 0,110 ; 0,558 \pm 0,089$; dan $0,515 \pm 0,101$ $\mathrm{kg} / \mathrm{ekor} / \mathrm{hari}$. Berdasarkan hasil penelitian maka disarankan bahwa untuk penerapan di lapangan agar produksi susu meningkat dan memberi manfaat ekonomi sebaiknya digunakan daun kering Kaliandra sebanyak $20 \%$ sebagai pengganti konsentrat.
\end{abstract}

Kata kunci: FCM susu, sapi perah, bahan kering, laktosa susu.

\section{PENDAHULUAN}

Peranan usaha ternak sapi perah rakyat sangat besar sebagai sumber penghasilan keluarga dan penyerapan tenaga kerja di pedesaan. Namun demikian, usaha sapi perah sampai saat ini belum mampu menjadikan peternaknya hidup sejahtera. Berbagai faktor internal dapat diupayakan untuk meningkatkan pendapatan peternak sapi perah rakyat dan dapat dikontrol. Sementara itu faktor yang bersifat eksternal terutama harga susu peternak tidak mempunyai posisi tawar cukup. Harga susu sangat tergantung pada tingkat harga yang ditetapkan Industri Pengolah Susu (IPS) beserta seperangkat syarat kualitasnya. Dalam kondisi pasar oligopsonistik tersebut, upaya perbaikan pendapatan dapat dilakukan dengan cara perbaikan pengelolaan usaha sehingga mencapai suatu kondisi usaha ternak sapi perah yang efisien. Pada usaha ternak sapi perah nilai penjualan susu ditentukan oleh jumlah susu yang dihasilkan dan tingkat harga yang dipengaruhi oleh tingginya kualitas susu. Karena itu, total nilai penerimaan usaha sangat tergantung pada kualitas dan kuantitas susu yang dihasilkan. Variabel terbesar yang 
mempengaruhi kuantitas dan kualitas susu pada usaha ternak sapi perah ditentukan oleh kuantitas dan kualitas pakan. Makin baik pakan yang diberikan pada sapi maka jumlah dan kualitas hasil akan makin memuaskan. Di sisi lain, penyediaan pakan yang makin baik menuntut korbanan biaya yang makin besar yang bagi peternak mempunyai konsekuensi mengurangi keuntungan atau penerimaan usaha mereka.

Laju pertumbuhan positif pada peternakan sapi perah di Pulau Jawa pada beberapa dekade belakangan ini tidak memperoleh dukungan yang cukup terutama dalam penyediaan lahan untuk tanaman pakan. Peluang perluasan lahan pakan di Pulau Jawa semakin kecil akibat maraknya alih fungsi lahan pertanian menjadi pemukiman dan kawasan industri. Peternak sering kesulitan dalam penyediaan pakan alami maupun asal limbah tanaman pangan pada musim kemarau.Di sisi lain sumber pakan hijauan yang berasal dari kawasan hutan kurang mampu dimanfaatkan secara optimal karena konversi lahan hutan yang tidak terarah dan perubahan iklim yang ekstrim. Akibatnya sering terjadi banjir dan erosi. Banjir dan erosi berdampak pada pemiskinan unsur hara. Hara mineral berbobot atom dan bervalensi rendah ikut tercuci dan tersisa hanyalah logam-logam berat polivalen yang toksis. Pada kondisi demikian vegetasi yang tumbuh di atas lahan tersebut menjadi terganggu. Dampak lanjutnya terjadi distorsi mineral pada ternak sehingga produktivitas ternak tidak optimum.

Mempertimbangkan kondisi peternakan sapi perah serta lahan sebagai basis usahanya, dipandang perlu adanya langkah antisipatif dalam menanggulangi rawan pakan. Penggunaan sumberdaya pakan alternatif seperti Kaliandra yaitu tanaman leguminosa yang juga berfungsi sebagai pencegah erosi diduga akan mampu menjadi pakan andalan dalam jangka panjang. Tanaman tersebut banyak tumbuh di hampir sebagian besar daerah pegunungan sebagai hasil gerakan reboisasi pada tahun 70 an dan sampai saat ini pemanfaatannya sebagai pakan ternak belum optimal. Pakan sapi perah secara umum dapat dikatagorikan menjadi pakan hijauan dan konsentrat. Pada usaha ternak sapi perah rakyat saat musim hujan pakan hijauan dapat disediakan dengan mudah tanpa mengeluarkan uang tunai karena masih dapat diperoleh dengan cara menyabit di lahan-lahan umum, sawah, pinggiran hutan, bantaran kali, dan sebagian berasal dari kebun rumput yang sengaja ditanam. Namun kualitas hijauan yang sengaja tidak ditanam mempunyai nilai yang rendah. Permasalahan lainnya dalam penyediaan hijauan adalah ketersediaannya pada musim kemarau sangat jauh berkurang serta kualitasnya sangat menurun. Padahal produksi susu sapi perah sangat peka terhadap fluktuasi perubahan pakan. Pada saat kualitas dan kuantitas pakan rendah produksi susu turun secara drastis dan memakan waktu lama untuk sampai pada capaian produksi sebelumnya. Karena itu, untuk mengatasi masalah kelangkaan pakan di musim kemarau peternak harus mempunyai cadangan pakan dengan kualitas baik dan kuantitas memadai.

Penambahan pakan konsentrat pada ransum secara ekonomi dinilai sangat tidak efisien karena besarnya porsi biaya konsentrat mendekati $100 \%$ dari total biaya pakan. Makin besar biaya konsentrat maka pendapatan peternak terkuras dan sebaliknya bila biaya pakan konsentrat dapat ditekan maka pendapatan peternak dapat ditingkatkan.

Kaliandra (Calliandra calothyrsus) adalah leguminosa pohon yang banyak dimanfaatkan sebagai pengendali erosi dan tanaman naungan. Kandungan nutrisi daun kaliandra cukup potensial sebagai pakan terutama sebagai pakan sumber protein yaitu mengandung 20-25 persen. Faktor pembatas pemanfaatannya adalah tanin, namun tidak berpengaruh bila pemberiannya sekitar 30-40\% dalam ransum. Perbaikan tingkat produksi susu disertai dengan peningkatan kualitas akan membawa pengaruh pada total penerimaan dari hasil penjualan susu meningkat sedangkan pengurangan penggunaan konsentrat akan menghemat biaya pakan. Dengan demikian, substitusi Kaliandra pada ransum sapi perah akan mampu memberikan pengaruh pada peningkatan pendapatan peternak. Penelitian ini diharapkan mampu memberi informasi untuk mengetahui pengaruh pemberian kuantitas daun kering Kaliandra dalam ransum terhadap produksi susu sehingga diperoleh pakan alternatif yang dapat direkomendasikan.

\section{MATERI DAN METODE}

Penelitian ini menggunakan 16 ekor sapi perah laktasi periode laktasi 1 dan 2 pada bulan laktasi 4, 5, dan 6. Pengelompokan hewan percobaan berdasarkan pada berat badan dan produksi susu. Kelompok 1 terdiri dari sapi perah dengan berat badan 416-437 kg dan produksi $19,7-20,16 \mathrm{~kg} /$ hari atau rata-rata berat badan 424,13 $\mathrm{kg}$ dan produksi 19,99 $\mathrm{kg} /$ hari. Kelompok 2 beranggotakan sapi perah berat badan 432,5-478 $\mathrm{kg}$ dan produksi 18,0$19,3 \mathrm{~kg} /$ hari atau rata-rata berat badan 430,63 $\mathrm{kg}$ dan produksi 18,39 kg/hari. Kelompok 3 mempunyai anggota sapi perah berat badan 363-455,5 kg dan produksi 16-17,42 kg/hari atau rata-rata berat badan $397,88 \mathrm{~kg}$ dan produksi 16,86 kg/hari. Kelompok 4 adalah kelompok sapi perah berat badan $384-447 \mathrm{~kg}$ dan produksi $10,58-13,0 \mathrm{~kg} /$ hari atau rata-rata berat badan $426 \mathrm{~kg}$ dan produksi 11,77 kg/hari. Ransum penelitian terdiri atas jerami dan 
ampas tahu yang disediakan oleh peternak dan ditambah dengan konsentrat produksi KSU Tandangsari. Pemberian konsentrat disesuaikan dengan jumlah produksi susu. Perlakuan percobaan penggunaan daun kering Kaliandra dilakukan sebagai berikut $\mathrm{R}_{1}=$ Jerami+ konsentrat KSU Tandangsari, $\mathrm{R}_{2}=$ Jerami $+90 \%$ konsentrat $+10 \%$ daun kering Kaliandra, $\mathrm{R}_{3}=$ Jerami $+80 \%$ konsentrat $+20 \%$ daun kering Kaliandra, dan $\mathrm{R}_{4}=$ Jerami $+70 \%$ konsentrat+30\% daun kering Kaliandra. Setiap sapi perlakuan mendapat jumlah jerami yang sama. Ransum yang diberikan untuk setiap ekor sapi laktasi terdiri atas campuran rumput dan konsentrat. Air minum diberikan ad libitum. Peubah yang diamati adalah produksi 4\% FCM, lemak, bahan kering, bahan kering tanpa lemak, protein, dan laktosa susu. Kandungan komponen susu dianalisis menggunakan alat dengan merek Milkana.
Penelitian ini dilakukan dengan menggunakan metode eksperimental. Rancangan yang digunakan adalah rancangan acak kelompok (RAK) dengan empat perlakuan ransum, setiap perlakuan diulang sebanyak empat kali yang juga merupakan kelompok. Efek perlakuan dari data yang didapat kemudian dianalisis dengan menggunakan analisis sidik ragam dan untuk menguji perbedaan antar perlakuan dilakukan uji kontras ortogonal.

\section{HASIL DAN PEMBAHASAN}

Jumlah produksi susu yang distandarisasi pada 4\% FCM, lemak, bahan kering, bahan kering tanpa lemak, protein, dan laktosa susu sebagai akibat perlakuan ditampilkan pada Tabel 1.

Tabel 1. Produksi Susu 4\% FCM, Lemak, Bahan Kering, Bahan Kering tanpa Lemak, Protein, dan Laktosa Susu Sapi Perah Fries Hollands Hasil Perlakuan Pemberian Daun Kering Kaliandra

\begin{tabular}{|c|c|c|c|c|}
\hline \multirow{2}{*}{ Variabel } & \multicolumn{4}{|c|}{ Perlakuan } \\
\hline & $\mathrm{R}_{1}$ & $\mathrm{R}_{2}$ & $\mathrm{R}_{3}$ & $\mathrm{R}_{4}$ \\
\hline & & 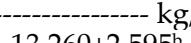 & or/hari --------- & \\
\hline Produksi susu 4\% FCM & $11,185 \pm 2,829^{a}$ & $13,260 \pm 2,595^{\mathrm{b}}$ & $13,135 \pm 1,124^{b}$ & $12,475 \pm 2,696^{\mathrm{b}}$ \\
\hline Lemak & $0,459 \pm 0,104$ & $0,460 \pm 0,102$ & $0,533 \pm 0,047$ & $0,516 \pm 0,121$ \\
\hline Bahan kering & $1,313 \pm 0,360$ & $1,520 \pm 0,305$ & $1,548 \pm 0,143$ & $1,493 \pm 0,309$ \\
\hline Bahan kering tanpa lemak & $0,855 \pm 0,254$ & $0,958 \pm 0,210$ & $1,014 \pm 0,112$ & $0,956 \pm 0,189$ \\
\hline Protein & $0,323 \pm 0,094$ & $0,365 \pm 0,079$ & $0,385 \pm 0,041$ & $0,370 \pm 0,071$ \\
\hline Laktosa & $0,454 \pm 0,136$ & $0,551 \pm 0,110$ & $0,558 \pm 0,089$ & $0,515 \pm 0,101$ \\
\hline
\end{tabular}
bertanda memberi makna tidak berbeda nyata $(\mathrm{P}>0,05)$.

Rata-rata perlakuan meningkat dengan adanya pemberian daun kering Kaliandra pda produksi susu 4\% FCM. Perlakuan memberi hasil $11,185 \pm 2,829$ untuk $\mathrm{R}_{1} ; 13,260 \pm 2,595$ untuk $\mathrm{R}_{2} ; 13,135 \pm 1,124$ untuk $\mathrm{R}_{3}$; dan $12,475 \pm 2,696$ kg/ekor/hari untuk $\mathrm{R}_{4}$. Pengujian secara statistik menunjukkan bahwa perlakuan berpengaruh nyata meningkatkan produksi susu $(\mathrm{P}<0,05)$ tetapi di antara perlakuan sendiri tidak memperlihatkan pengaruh yang nyata. Produksi susu lebih banyak dipengaruhi oleh lingkungan daripada sifat genetik. Faktor lingkungan terutama pakan memegang peranan penting terhadap proses fisiologis dalam tubuh sapi perah sehingga pada gilirannya mempengaruhi produksi susu (Johansson, 1961; Damron, 2003). Peningkatan produksi susu terjadi karena protein dalam ransum diubah oleh tubuh sapi perah menjadi produksi susu. Di samping itu, kadar lemak susu berasal dari serat kasar yang dicerna di rumen. Akibatnya, hasil perhitungan lebih lanjut antara produksi dan kadar lemak menampakkan bahwa produksi susu yang distandarisasi ke 4\% FCM juga meningkat. Hal ini sejalan dengan pendapat Bath, dkk. (1973), NRC (2001), dan Damron (2003) bahwa nutrisi terutama protein diperlukan untuk kesehatan dan produksi susu sapi perah. Pemberian ransum cenderung untuk mencapai produksi maksimal dengan biaya murah. Protein ransum digunakan oleh tubuh menjadi produksi susu setelah melalui proses fermentasi di rumen oleh mikroba rumen. Menurut Adkinson, dkk. (1993), terdapat hubungan antara pakan dan produksi susu dan perbandingannya menentukan besar nilai pendapatan peternak

Produksi lemak susu perlakuan $R_{1}$ sebesar 0,459 $\pm 0,104$; kemudian terjadi peningkatan pada $\mathrm{R}_{2} \quad 0,460 \pm 0,102 ; \mathrm{R}_{3}$

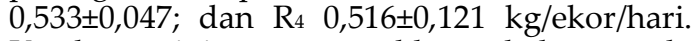
Keadaan ini menampakkan bahwa ada peningkatan produksi lemak sebagai akibat dari pemberian daun Kaliandra. Perbandingan jumlah produksi lemak antar perlakuan menunjukkan berbeda tidak nyata. Lemak susu merupakan hasil perombakan serat kasar menjadi asam setat, lemak darah, dan selanjutnya menjadi lemak susu. Kandungan lemak susu relatif sama merupakan akibat dari pemberian ransum dengan kadar serat kasar di atas 13\%. Menurut NRC (2001), kandungan serat kasar ransum sapi perah tidak boleh kurang dari 13\% karena dapat menurunkan kandungan lemak susu yang dihasilkan.

Produksi bahan kering susu meningkat yang dimulai dari $R_{1} 1,313 \pm 0,360$ dan 
mencapai puncaknya pada perlakuan $\mathrm{R}_{2}$ $1,520 \pm 0,305 \mathrm{~kg} / \mathrm{ekor} / \mathrm{hari}$. Selanjutnya produksi bahan kering menurun di perlakuan $R_{3}$ $1,548 \pm 0,143$ dan $R_{4}$ 1,493 $\pm 0,309$ kg/ekor/hari yang terjadi akibat pemberian daun Kaliandra. Pengujian secara statistik memperlihatkan bahwa tidak terdapat perbedaan antar kelompok perlakuan secara keseluruhan. Bahan kering merupakan hasil pengurangan seluruh kandungan air yang terdapat pada susu. Bahan kering terdiri dari komponenkompoenen susu yang berupa lemak, mineral, protein, gula, dan vitamin. Komponenkomponen ini terdapat dalam darah. Komponen darah dan susu relatif tidak banyak berubah kecuali lemak. Dengan demikian, kandungan bahan kering susu juga tidak banyak berubah (Damron, 2003). Jumlah produksi bahan kering tanpa lemak susu perlakuan $\mathrm{R}_{1}$ sebesar 0,855 $\pm 0,254 \mathrm{~kg} /$ ekor/hari dan nilai ini lebih rendah dibandingkan perlakuan $R_{2}$ 0,958 $\pm 0,210 ; R_{3} 1,014 \pm 0,112$; dan $R_{4}$ $0,956 \pm 0,189 \mathrm{~kg} / \mathrm{ekor} / \mathrm{hari}$. Pengujian secara statistik dapat membuktikan bahwa perlakuan memberi hasil yang berbeda tetapi tidak nyata di antara perlakuan. Keadaan ini sudah jelas dapat dimengerti karena perlakuan juga tidak memperlihatkan hasil yang berbeda dalam hal produksi bahan kering dan lemak susu. Perlakuan $\mathrm{R}_{1}$ memberi hasil produksi protein susu sebanyak 0,323 $\pm 0,094 \mathrm{~kg} / \mathrm{ekor} / \mathrm{hari}$. Selanjutnya produksi protein susu meningkat pada perlakuan $R_{2} \quad 0,365 \pm 0,079$ sampai $R_{3}$ $0,385 \pm 0,041$ dan kemudian menurun lagi pada $\mathrm{R}_{4}$ 0,370 $\pm 0,071 \mathrm{~kg} / \mathrm{ekor} / \mathrm{hari}$ tetapi $\mathrm{R}_{4}$ masih lebih tinggi dari $R_{1}$. Pengujian statistik perlakuan pemberian daun kering Kaliandra menunjukkan perbedaan tidak nyata dalam produksi protein susu. Menurut pendapat Alim, dkk. (2002) dan Damron (2003) bahwa nutrisi diperlukan untuk kesehatan dan produksi susu sapi perah. Protein ransum digunakan oleh tubuh menjadi produksi susu. Mikroba rumen dan sapi perah adalah makhluk biologis sehingga ada keterbatasan dalam proses fisiologisnya. Akibat lanjut yaitu protein yang dibentuk oleh mikroba rumen dan sapi perah relatif sama walau jumlah protein ransum ditingkatkan.

Perlakuan $\mathrm{R}_{1}$ memberi hasil produksi laktosa susu sebanyak 0,454 $\pm 0,136$ $\mathrm{kg} / \mathrm{ekor} / \mathrm{hari}$. Selanjutnya produksi protein susu meningkat pada perlakuan $R_{2} 0,551 \pm 0,110$ sampai $R_{3}$ 0,558 $\pm 0,089$ dan kemudian menurun lagi pada $R_{4} 0,515 \pm 0,101 \mathrm{~kg} /$ ekor/hari tetapi $R_{4}$ masih lebih tinggi dari $\mathrm{R}_{1}$. Pengujian statistik memberi hasil bahwa perlakuan berpengaruh tidak nyata terhadap jumlah produksi laktosa susu. Menurut pendapat University of Guelph (2002), Damron (2003), dan Delaval (2005) bahwa protein susu tidak banyak berubah setelah melalui masa kolostrum.

\section{SIMPULAN DAN SARAN}

\section{Simpulan}

Pengujian secara statistik serta hasil dan pembahasan memberi kesimpulan pada penelitian ini bahwa pemberian daun kering Kaliandra (C. calothyrsus) sebagai pengganti konsentrat berpengaruh terhadap jumlah produksi susu 4\% FCM ( $\mathrm{R}_{2}$ lebih besar dari R1,R3 dan R4) dan tidak berpengaruh terhadap komponen lemak, bahan kering, bahan kering tanpa lemak, protein dan laktosa susu sapi perah Fries Holland.

\section{Saran}

Untuk penerapan di lapangan agar produksi susu meningkat disarankan sebaiknya digunakan daun Kaliandra sebanyak $20 \%$ sebagai pengganti konsentrat.

\section{DAFTAR PUSTAKA}

Adkinson, R.W., W.S. Fammer, and B.F. Jenny. 1993. Feeding Practice and Income Over Cost on Pasture Oriented Dairy Farm in Lousiana. J. Dairy Sci., 76:3547-3554.

Alim, A.F., T. Hidaka, dan T. Nakanishi. 2002. Pakan dan Tatalaksana Sapi Perah. Cetakan Pertama. Penerbit Dairy Technology Improvement Project in Indonesia. Bandung. Hal. 1-122.

Bath, D.L., F.N Dickinson, H.A. Tucker, and R.D. Appleman. 1978. Dairy Cattle, Principles, Practices, Problems, Profits. $2^{\text {nd }}$ Ed., Lea and Febiger. Philadelphia. p. 311.

Damron, W.S. 2003. Introduction to Animal Science: Global, Biological, Social, and Industry Prospective. Second Ed., Pearson Education, Inc., Upper Saddle River, New Jersey. Pp. 71-94, 239-248.

Delaval. 2005. http://www.delaval.com

Johansson, I. 1961. Genetic Aspects of Dairy Cattle Breeding. Illinois University Press. Urbana. Pp. 1-5.

Macqueen, D. 1997. Botany and Ecology. In Calliandra calothyrsus Production and Use: A Field Manual. Ed. By Powel, M.H., Forest, Farm, and Community Tree Network. Winrock International and Taiwan Forestry Research Institute. Morilton, Arkansas, USA. Pp.1-6.

National Research Council (NRC). 2001. Nutrients Requirement of Dairy Cattle. $7^{\text {th }}$ Rev. Ed., Washington D.C.

University of Guelph. 2002. http://www.foodsci:uoguelph.ca/dairyd $\underline{\mathrm{u} / \text { TDT.html }}$ 